\title{
A Case of Laryngeal Lymphoepithelial Carcinoma
}

\author{
Dong Gyu Choi' ${ }^{(\mathbb{D}}$, Young-Ok Kim² (D) and Hyoung Shin Lee ${ }^{1}$ (i) \\ ${ }^{1}$ Departments of Otolaryngology-Head and Neck Surgery and 'Pathology, Kosin University College of Medicine, Busan, Korea
}

\section{후두에 발생한 림프상피암종 1예}

최동규 ${ }^{1}$, 김영옥 ${ }^{2}$, 이형신 ${ }^{1}$

고신대학교 의과대학 이비인후-두경부외과학교실, ${ }^{1}$ 병리학교실2

\begin{abstract}
Laryngeal lymphoepithelial carcinoma (LEC) is a rare tumor with only 34 cases in the published literature. Epidemiologically, laryngeal LEC is extremely rare in Asian. Originally, LEC is a common type of carcinoma in nasopharynx. Laryngeal LEC resembles nasopharyngeal LEC, except that most cases of laryngeal LEC are not associated with Epstein-Barr virus. We present a case of laryngeal LEC which developed at the left false cord extending to true vocal cord, para-glottic space and pre-epiglottic space. Total laryngectomy with bilateral neck dissection was performed. LEC was reported as biopsy confirmation result. The patient underwent postoperative radiotherapy and showed no evidence of recurrence during follow-up period of 42 months. In consideration that LEC in larynx have not been reported in South Korea yet, we introduce the clinical features and treatment outcomes of laryngeal LEC with literature review.
\end{abstract}

Keywords Lymphoepithelial carcinoma; Larynx; Laryngectomy; Radiotherapy.

\section{서 론}

림프상피암종은 미분화된 비인두암종에서 가장 흔한 암종이다[1]. 이는 비인두에 발 생하는 암의 $40 \%$ 를 차지한다[2,3]. 이외에도 이하선을 포함한 침샘, 흥선, 폐, 위, 식도, 자궁경부, 유방, 방광과 피부에서도 드물게 발생한다[1,4,5].

림프상피암종은 발생 부위에 따라 다양한 임상 양상을 보이는데 주로 비인두에 발생하 여 비출혈, 비폐색, 전음성난청, 뇌신경마비 등의 증상이 나타날 수 있다[6]. 후두에 림 프상피암종이 발생하는 경우, 가장 흔한 증상은 애성과 연하 곤란이다[7]. 제한된 증례로 인해 아직 후두 림프상피암종의 치료 방법에 대해 확립된 바는 없지만 방사선 치료에 잘 반응하기 때문에 수술과 방사선 치료를 고려할 수 있는 것으로 알려져 있다 $[5,6,8]$.

후두 림프상피암종은 후두에서 발생하는 암종에서 비교적 드문 형태로 국내에는 후 두에 발생한 림프상피암종에 대한 보고된 바가 없어 본 증례를 소개하고, 그 임상 양상 을 살펴보고 문헌 고찰하고자 한다.

\author{
Received October 21, 2020 \\ Revised November 16, 2020 \\ Accepted November 18, 2020 \\ Corresponding Author \\ Hyoung Shin Lee, MD, PhD \\ Department of Otolaryngology- \\ Head and Neck Surgery, \\ Kosin University \\ College of Medicine, \\ 262 Gamcheon-ro, Seo-gu, \\ Busan 49267, Korea \\ Tel +82-51-990-6470 \\ $\mathrm{Fax}+82-51-245-8539$ \\ E-mail sego78@hanmail.net
}

\section{ORCID iDs}

Dong Gyu Choi (D)

https://orcid.org/0000-0002-3632-7967

Young-Ok Kim (D)

https://orcid.org/0000-0003-3021-2621

Hyoung Shin Lee (D)

https://orcid.org/0000-0002-6200-1979

\footnotetext{
This is an Open Access article distributed under the terms of the Creative Commons Attribution Non-Commercial License (https://creativecommons.org/ licenses/by-nc/4.0) which permits unrestricted non-commercial use, distribution, and reproduction in any medium, provided the original work is properly cited.
} 


\section{증 례}

72세 남자가 애성 증상이 있어 수개월간 경구 약제를 복 용하며 경과 관찰하였으나 증상 호전이 없었다. 외부 병원에 서 시행한 조직검사상 상피암(carcinoma)으로 보고되어 치 료를 위해 본원으로 의뢰되었다. 과거력상 2010년 뇌졸중으 로 입원 치료를 받았던 병력이 있었으며, 음주력은 없었고, 50 갑년의 흡연력이 있었다.

후두내시경상 좌측 성대를 포함한 성문상부의 종물이 관 찰되었고, 성대마비 소견은 관찰되지 않았으며(Fig. $1 \mathrm{~A}$ ), 경 부 전산화단층촬영상 좌측 성문상부의 종양이 성문주위 공 간 및 후두덮개 앞 공간, 갑상연골 및 성문까지 침범된 소견 을 확인할 수 있었다. 갑상연골의 침범은 내측 연골막을 침범 하는 상태로 확인되었다. 양측 경부림프절의 다발성 전이가 확인되어 좌측은 세침흡인검사, 우측은 중심부바늘생검을 통해 전이성 병변임을 확인하였다(Fig. 1B). 양전자방출단층 촬영상에서 대장 용종으로 확인된 병변 외에 전신 전이 소견 은 확인되지 않았다. 좌측 성문상부암(cT3N2cM0, stage IVa) 진단하에 2017년 3월 16일 후두전절제술, 좌측 선택적 경부곽 청술(level II V)(흉쇄유돌근 희생), 우측 선택적 경부곽청술 (level II V) 및 인공발성관(Provox ${ }^{\circledR} \mathrm{Vega}^{\mathrm{TM}}$, Atos Medical $\mathrm{AB}$, Hörby, Sweden) 삽입술을 시행하였다(Fig. 2).

수술 후 최종 조직검사상 $2.0 \times 1.5 \times 1.2 \mathrm{~cm}$ 크기의 림프상 피암종으로 확인되었으며 절제변연은 음성으로 확인되었다. 현미경 소견에서 암종은 세포질의 경계가 명확하지 않은 난 원형의 세포가 판상으로 배열하였으며, 핵은 크고 수포성이며 핵 안에 뚜렷한 핵소체가 관찰되었다. 종양세포의 주변에는 많 은 수의 소림프구가 보였다(Fig. 3). 45개의 적출된 림프절 중 4개의 림프절(우측, level II 3개; 좌측, level III 1개)에서 전이 가 확인되었다. 림프절 내 종양의 최대 크기는 $1.8 \mathrm{~cm}$ 로 확인 되었으며, 림프절 외 침범 소견은 없었다. 수술 후 조직검사 결

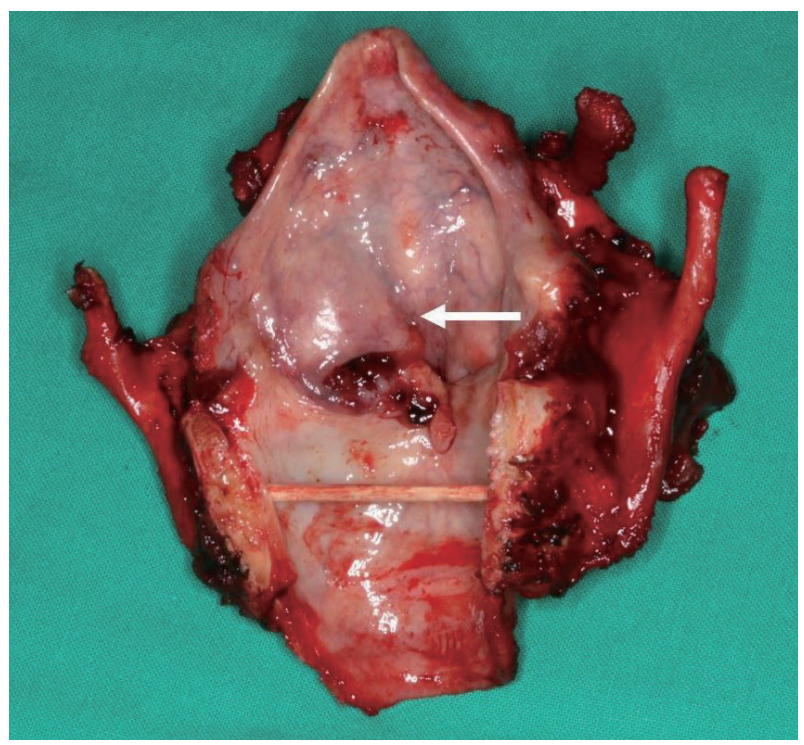

Fig. 2. Gross tissue specimen of total laryngectomy. Mass located at left false cord with extension to left true vocal cord (arrow) is identified.

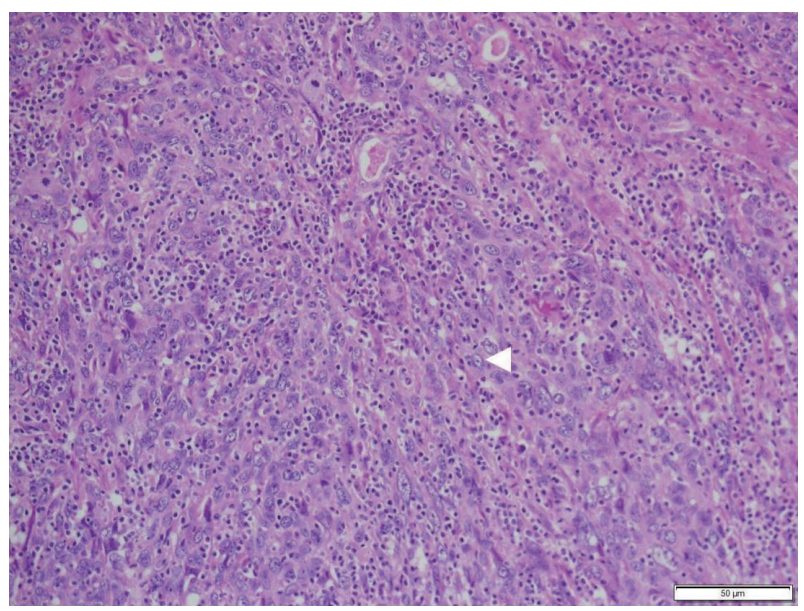

Fig. 3. Microscopic findings (hematoxylin and eosin staining, $\times 200$ ). Tumor is composed of syncytial tumor nests. Tumor cells are characterized by vesicular nuclei with prominent nucleoli (arrowhead). Tumor cells are infiltrated by lymphocytes.
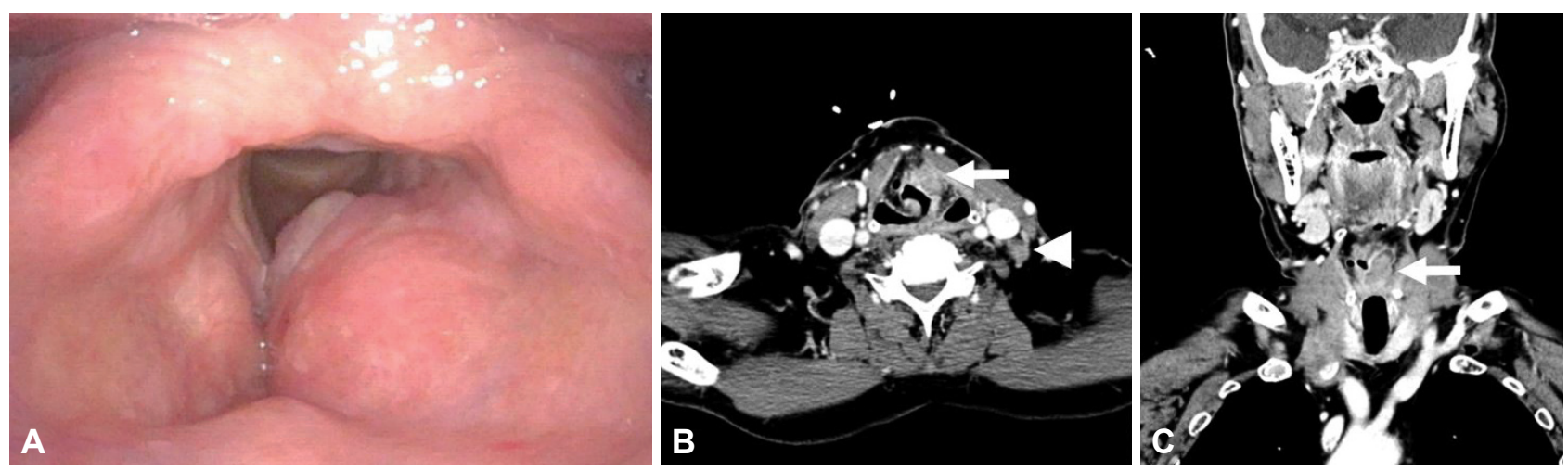

Fig. 1. Preoperative laryngoscope and neck CT finding. A: Preoperative laryngoscope shows left supraglottic mass extending to true vocal cord with mild ulceration. B: Left supraglottic mass (arrow) and left lymph node enlargement (arrowhead) are identified in preoperative neck CT (axial view). C: Left supraglottic mass (arrow) is identified in preoperative neck CT (coronal view). 
과를 바탕으로 병리적 병기는 pT3N2cM0로 확인되었다. 수술 1 주일 후 식도조영술상 누출 등 특이 소견이 없음을 확인하 고 경구 식이를 시작했으며, 수술 후 14 일째 특이 합병증 없이 퇴원하였다.

양측 경부 림프절 전이로 수술 후 항암방사선 병합 치료를 고려하였으나 만성신부전으로 콩팥 기능 저하를 고려하여 항 암치료는 시행하지 않았으며, $5040 \mathrm{cGy}(180 \mathrm{cGy} /$ 일, 28회) 방 사선 치료를 시행하였다. 이후 환자는 수술 후 3년 6개월 동 안 재발 소견 없이 경과 관찰 중이다.

\section{고 찰}

림프상피암종은 후두에서 발생하는 암종에서 비교적 드문 형태의 암종으로, 현재까지 약 34건이 문헌 보고되어 있다[8]. 이는 후두에 발생한 악성 종양의 약 $0.2 \%$ 을 차지한다[1,3,9]. 지금까지 보고된 후두의 림프상피암종은 대부분 성문상부에 서 기원하는 것으로 알려져 있다[2,4,9]. 종양의 위치에 따라 대부분의 환자는 하나 이상의 주소가 있었으며, 그 중 가장 흔한 증상은 애성과 연하 곤란이었다[7]. 본 증례에서는 종양 이 성문상부를 침범하여 애성 증상이 있었다. 역학적으로 아 시아인에 비해 백인에 더 흔하고, 남성에게서 더 흔하고, 평균 발병 연령은 60대이다[10].

문헌에 보고된 30예 중 23예는 경부곽청술 시행 후 림프절 전이를 확인할 수 있었다[5]. MacMillan 등[8]에 의하면 8예 의 경부곽청술 후 7예가 림프절 전이 소견이 확인되었고, 그 중 1 예가 양측 경부림프절 전이가 있었다. 본 증례의 경우 우 측에 3 개, 좌측에 1 개의 림프절 전이가 있었다.

림프상피암종의 병리학적 특징은 세포질의 경계가 명확하 지 않은 난원형의 세포가 판상으로 배열되고, 핵은 크고 수포 성이며 핵 안에 뚜렷한 핵소체가 관찰된다는 점이다. 또한 주 변의 림프구가 관찰되는 점도 특징적인데, 본 증례에서도 큰 수포성 핵과 핵소체와 함께 분명한 이형성을 보였고 종양세 포의 주변에는 많은 수의 소림프구가 관찰되어 림프상피암종 으로 진단될 수 있었다. 편평상피암종과의 감별이 필요한데, 편평상피암종에서 보이는 다각형의 세포와 각질화의 소견은 관찰되지 않는다는 특징을 통해 감별할 수 있다. 본 증례도 다 각형 세포와 각질화 소견은 보이지 않아 편평세포암종은 배 제할 수 있었다. 현미경 소견은 비인두에서 발생하는 림프상 피암종과 동일한 모습이지만, 후두의 림프상피암종은 비인두 에서 기원한 종양과 다르게 Epstein-Barr virus(EBV)와의 연 관성이 드물다[2,5,8]. 후두의 림프상피암종에서 $\mathrm{EBV}$ 와 관련 된 명확한 기전과 $\mathrm{EBV}$ 의 유무가 예후나 치료에 어떤 유의미 한 차이가 있는지는 밝혀지지 않았다[7,8]. 현재까지 보고된
후두의 림프상피암종 증례 중 $\mathrm{EBV}$ 관련 검사를 시행한 17예 중 5예가 양성으로 확인되었다[1]. 그러나 본 증례에서는 $\mathrm{EBV}$ 관련 검사는 시행하지 못했다. 주요 감별 진단으로는 비호지 킨 림프종과 편평상피세포암이 있다[7]. 정확한 병리학적 소 견과 임상 양상을 바탕으로 올바른 진단을 내리는 것이 치료 에 중요한 요소가 된다. 하지만 현재까지 보고된 증례가 적어 적절한 치료 방법을 선택하는 데 어려움이 있다[7].

후두의 림프상피암종은 매우 공격적인 특성을 가지고 있다 [3]. 경부 림프절 전이는 $75 \%$ 에서, 전신 전이는 $29 \%$ 에서 관찰 되었으며, 5 년 생존율은 $63 \%$ 로 보고된다[10]. 대부분의 환자 는 원격 전이로 인해 사망을 한다[8].

후두의 림프상피암종은 공격적이나 방사선 치료에 효과적 으로 반응하기 때문에 수술 또는 방사선 치료, 또는 수술 후 방사선 치료를 고려해볼 수 있다[5,6,8]. Marioni 등[7]에 의하 면 현재까지 보고된 34건의 후두 림프상피암종의 치료 방법 으로서 방사선 치료 단독 7예, 수술적 치료 단독 8예, 수술과 함께 방사선 치료를 시행한 경우 13 예, 치료의 언급이 없는 것 을 포함하여 기타 6예가 있었다. 치료 결과는 방사선 치료는 5 예가 재발의 증거가 없었다. 수술만 시행한 경우 5 예가 재발 의 증거가 없었고, 수술과 방사선 치료를 함께 시행한 경우 8예 가 재발의 증거가 없었다고 보고하였다. 제한된 증례로 인해 현재까지는 여러 치료 방법들의 효과에 대한 명확한 비교가 어렵지만, 진행된 후두의 림프상피암종에 있어서 수술적 절제 후 방사선 치료를 시행하는 것이 바람직하다. 그러나, 이전의 문헌 보고에서 단일 치료(수술 또는 방사선)와 복합 치료의 비 교는 일반적으로 진행된 병기에서 복합 치료를 시행하기 때문 에 병기가 교란 변수가 될 수 있다[4]. 대부분의 환자가 원격 전이로 인해 사망한다는 점을 고려하면, 원격 전이가 있을 경 우 적절한 항암 치료를 통해 원격 전이에 대한 치료를 시행해 야 하는데[8] 본 증례에서는 종양 회의를 통해 수술 후 항암 치료를 시행하지 않았고 현재까지 원격 전이 소견 없이 경과 관찰 중이다.

후두에서 발생한 림프상피암종은 현재까지 국내에서는 보 고가 된 적 없는 매우 드문 질환이다. 향후 발생하는 추가적인 증례와 연구를 통해서 적절한 치료 방법과 병인에 대해 알아 볼 필요가 있다.

중심 단어: 림프상피암종, 후두, 후두절제술, 방사선 치료.

Acknowledgments

None.

Conflicts of Interest

The authors have no financial conflicts of interest. 


\section{Authors' Contribution}

Conceptualization: Hyoung Shin Lee. Data curation: Dong Gyu Choi. Formal analysis: Dong Gyu Choi, Hyoung Shin Lee. Methodology: Young-Ok Kim. Supervision: Hyoung Shin Lee. Writingoriginal draft: Dong Gyu Choi. Writing_review \& editing: Young-Ok Kim, Hyoung Shin Lee. Approval of final manuscript: all authors.

\section{REFERENCES}

1. Kermani W, Belcadhi M, Sriha B, Abdelkéfi M. Epstein-Barr virusassociated lymphoepithelial carcinoma of the larynx. Eur Ann Otorhinolaryngol Head Neck Dis 2015;132(4):231-3.

2. Hammas N, Benmansour N, El Alami El Amine MN, Chbani L, El Fatemi H. Lymphoepithelial carcinoma: a case report of a rare tumor of the larynx. BMC Clin Pathol 2017;17:24.

3. Monteiro F, Baldaia H, Ribeiro L, Sousa M, Oliveira P, Ferreira E, et al. Epstein-Barr virus-associated with lymphoepithelial carcinoma: a rare tumor of the larynx. Clin Med Insights Ear Nose Throat 2019; 12:1179550619865551

4. Faisal M, Hartenbach S, Schratter A, Köstler WJ, Kaufmann H, See- mann R, et al. Lymphoepithelial carcinoma of larynx and hypopharynx: a rare clinicopathological entity. Cancers (Basel) 2020;12(9):2431.

5. Coskun BU, Cinar U, Sener BM, Dadas B. Lymphoepithelial carcinoma of the larynx. Auris Nasus Larynx 2005;32(2):189-93.

6. Chen YP, Chan ATC, Le QT, Blanchard P, Sun Y, Ma J. Nasopharyngeal carcinoma. Lancet 2019;394(10192):64-80.

7. Marioni G, Mariuzzi L, Gaio E, Portaleone S, Pertoldi B, Staffieri A. Lymphoepithelial carcinoma of the larynx. Acta Otolaryngol 2002; 122(4):429-34.

8. MacMillan C, Kapadia SB, Finkelstein SD, Nalesnik MA, Barnes L. Lymphoepithelial carcinoma of the larynx and hypopharynx: study of eight cases with relationship to Epstein-Barr virus and p53 gene alterations, and review of the literature. Hum Pathol 1996;27(11):1172-9.

9. Ibrahimov M, Yilmaz M, Celal MH, Mamanov M, Yollu U, Ozek H. Lymphoepithelial carcinoma of the larynx. J Craniofac Surg 2013;24 (3):1049.

10. Acuña G, Gomà M, Temprana-Salvador J, Garcia-Bragado F, Alós L, Ordi J, et al. Human papillomavirus in laryngeal and hypopharyngeal lymphoepithelial carcinoma. Mod Pathol 2019;32(5):621-26. 